\title{
The Effect of Prehospital Fluid Resuscitation on Mortality and Post-trauma Recovery Time in Trauma Patients
}

\section{Travma Hastalarında Hastane Öncesi Sıvı Resusitasyonunun Mortalite ve Post-travma İyileşme Süresine Etkisi}

\author{
(D) Figen Tunalı Türkdoğan1, (D) Abuzer Coşkun²
}

1Bahçelievler Physical Therapy and Rehabilitation Training and Research Hospital, Clinic of Radiology, İstanbul, Turkey
2University of Health Sciences Turkey, İstanbul Bağcllar Training and Research Hospital, Clinic of Emergency Medicine, İstanbul, Turkey

\section{Abstract}

Objective: It was aimed to evaluate the effect of pre-hospital fluid resuscitation on serum lactate level, mortality, radiological imaging, and late post-trauma recovery (PRT) in patients with trauma, who were admitted to the emergency department.

Method: In this study, 532 patients over the age of 18 years, who were admitted to the emergency department due to trauma between January 1, 2016, and December 31, 2017, were included. The average age of the patients was $37.19 \pm 13.91$ years, 378 (71\%) were male and $154(29 \%)$ were female. The demographic characteristics, fluid resuscitation, and serum lactate levels, trauma patterns, mortality, and PRT results of these patients were evaluated retrospectively.

Results: PRT duration was shorter (22.48 \pm 7.17 days) in patients who underwent prehospital fluid resuscitation and longer (26.85 \pm 7.58 days) in those who did not receive it. Also, lactate levels were significantly lower in liquid areas $(2.18 \pm 1.05 \mathrm{mmol} / \mathrm{L})$ compared to those that did not take it $(2.61 \pm 1.40 \mathrm{mmol} / \mathrm{L})$. PRT time was $24.20 \pm 7.34$ days in the group without mortality, and $33.43 \pm 12.87$ days in the group with mortality. Serum lactate level was $2.29 \pm 1.10 \mathrm{mmol} / \mathrm{L}$ in the group without mortality, and $5.51 \pm 1.87 \mathrm{mmol} / \mathrm{L}$ in the group without mortality. Serum lactate levels were $2.29 \pm 1.10 \mathrm{mmol} / \mathrm{L}$ in liquid areas and $5.51 \pm 1.87 \mathrm{mmol} / \mathrm{L}$ in those who did not receive it. Types of trauma were associated with fluid resuscitation and radiological imaging methods $(p=0.001)$. These parameters showed a moderate and/or strong positive correlation among themselves, as well as in terms of lactate, PRT duration, and mortality. ROC curve analysis was performed to predict the development of mortality. The rates of lactate and PRT were over $45 \%$ with a sensitivity of $97.7 \%$ and a specificity of $94.3 \%$ and with a sensitivity of $89.7 \%$ and a specificity of $83.6 \%$, respectively.

\section{Öz}

\begin{abstract}
Amaç: Acil servise başvuran travmalı hastalarda, hastane öncesi sıvı resusitasyonunun serum laktat düzeyi, mortalite, radyolojik görüntüleme ve geç post-travma iyileşmesine (PRT) etkisi amaçlandı.
\end{abstract}

Yöntem: Bu çalışmaya, 1 Ocak 2016-31 Aralık 2017 tarihleri arasında acil servisine travma nedeniyle başvuran 18 yaşından büyük 532 hasta dahil

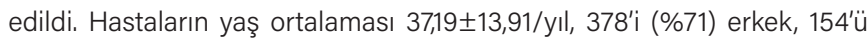
(\%29) kadındı. Bu hastaların demografik özellikleri, sıvı resusitasyonu ve serum laktat düzeyleri, travma şekilleri, mortalite ve PRT sonuçları retrospektif olarak değerlendirildi.

Bulgular: Hastane öncesi SIVı resusitasyonu yapılan hastalarda PRT süresi kısa (22,48 $\pm 7,17$ gün), almayanlarda daha uzundu $(26,85 \pm 7,58$ gün). Ayrıca laktat düzeyi sıvı alanlarda (2,18 $\pm 1,05 \mathrm{mmol} / \mathrm{L})$, almayanlara $(2,61 \pm 1,40 \mathrm{mmol} / \mathrm{L})$ göre anlamlı olarak düşük bulundu.

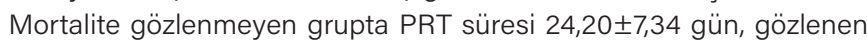
grupta ise $33,43 \pm 12,87$ gün olduğu tespit edildi. Serum laktat düzeyi mortalite gözlenmeyen grupta 2,29 $\pm 1,10 \mathrm{mmol} / \mathrm{L}$, gözlenmeyen grupta $5,51 \pm 1,87 \mathrm{mmol} / \mathrm{L}$ olarak saptandı. Serum laktat düzeyi

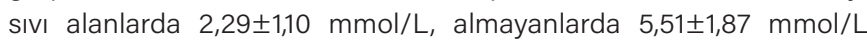
olarak saptandı. Travma çeşitleri, sıvı resusitasyonu ve radyolojik görüntüleme yöntemleriyle ilişkiliydi $(p=0,001)$. Bu parametreler kendi aralarında, ayrıca laktat, PRT süresi, mortalite açısından, orta ve/veya güçlü pozitif yönlü bir ilişki sergiledi. Mortalitenin gelişimini tahmin etmek için ROC curve analize yapıldı. Laktat \%97,7 duyarlılık ve \%94,3 özgüllük, PRT \%89,7 duyarlılık ve \%83,6 özgüllük ile \%45'in üzerinde bulunmuştur.

Address for Correspondence: Figen Tunalı Türkdoğan, Bahçelievler Physical Therapy and Rehabilitation Training and Research Hospital, Clinic of Radiology, İstanbul, Turkey

E-mail: turkdogandr@gmail.com ORCID: orcid.org/0000-0003-2075-1322 Received: 02.02.2021 Accepted: 20.04.2021

Cite this article as: Tunalı Türkdoğan F, Coşkun A. The Effect of Prehospital Fluid Resuscitation on Mortality and Post-trauma Recovery Time in Trauma Patients. Bagcilar Med Bull 2021;6(2):174-182

${ }^{\circ}$ Copyright 2021 by the Health Sciences University Turkey, Bagcilar Training and Research Hospital Bagcilar Medical Bulletin published by Galenos Publishing House. 


\section{Abstract}

Conclusion: Mortality and morbidity rates can be reduced by early detection of trauma cases with multidisciplinary understanding, adjustment of fluid and lactate levels, and early decision-making on the procedures to be performed.

Keywords: Fluid resuscitation, lactate, mortality, post-trauma recovery, trauma

\section{Öz}

Sonuç: Travma olgularının erken multidisipliner bir anlayışla saptanması, sıvı ve laktat düzeyinin ayarlanması ve yapılacak işlemlerin kararının erken verilmesi ile mortalite ve morbidite oranları düşürülebilir.

Anahtar kelimeler: Laktat, mortalite, post-travma iyileşme, sıvı resusitasyonu, travma

\section{Introduction}

Trauma is one of the most important causes of young age deaths and causes serious disabilities (1). Despite technological developments and measures taken, 5.8 million people are lost in the world every year due to various injuries. This constitutes $10 \%$ of all deaths in the world (2). Trauma-related deaths are divided into three groups: prehospital, emergency, and intensive care. According to the reports of the World Health Organization, when all age groups are evaluated, traffic accidents rank $10^{\text {th }}$ among the most common causes of death in the world and constitute $2.1 \%$ of all deaths (3). According to estimates, if the number of injured continues to increase rapidly, trauma will be ranked $3^{\text {rd }}$ among "Causes of Death in the World" in 2020 (2).

Bleeding, the preventable cause of death that occurs in the first 24 hours after trauma, is responsible for $30-40 \%$ of trauma-related mortality (4). The general approach is to perform an intravenous fluid replacement, which begins at the site of the trauma and during the patient's transfer. However, some publications contain evidence that this practice may not be the right approach in all trauma patients (5). In some studies, there are opinions that as patients' time to reach the hospital increases, the risk of death due to intravenous route opening and fluid replacement application at the scene and during transfer also increases $(6,7)$. It has been reported that prehospital fluid administration in penetrating trauma can increase bleeding and mortality, so delaying fluid resuscitation may be appropriate in these patients. For patients with blunt trauma, studies on this subject remain limited (8).

The markers we will use to decide the adequacy of resuscitation in patients with trauma should also be a reliable parameter in the follow-up of tissue hypoxia. In practice, keeping vital parameters such as blood pressure, urine output, and heart rate within normal limits is used to evaluate the effectiveness of the resuscitation, but it is a fact that these criteria are not sufficient alone in the resuscitation of critically ill patients. In this respect, two markers commonly used today to evaluate the effectiveness of resuscitation are base deficit and lactate. Base deficit and lactate level measured for the first time after trauma can be used as early indicators in determining the prognosis of shock. Early identification of patients prone to shock after trauma and effective resuscitation of these patients are also very important in terms of prognosis. Therefore, centers dealing with trauma prefer blood gas analysis and base deficit values, the results of which can be obtained immediately, to manage the treatment (9). Lactate measurements in arterial blood gas can be used as a predictor of post-traumatic tissue hypoxia and metabolic acidosis. Serial lactate measurements may be useful in predicting mortality in trauma patients (10).

In parallel with the resuscitation and stabilization efforts in the first hour, which is called the "golden hour", it is of great importance to start radiological examinations to have an idea about the extent of trauma in patients before treatment. Initial radiological examinations to be performed on patients with polytrauma are divided into 4 groups: First, X-ray examinations to be performed in trauma patients include direct and contrast-enhanced examinations. Second, ultrasonographic examinations are inexpensive, practical, non-invasive applications that can be used safely in determining free fluid in the abdomen with significant parenchymal damage in hemodynamically unstable patients. Thirdly, while computed tomographic examinations can display all body parts, high accuracy data can be obtained regarding the functions of most organs with the contrast agents given. Therefore, some advocate the use of head, thorax, abdomen, and extremity computed tomography (CT) as a non-invasive, more advantageous, and highly accurate method in patients with initial polytrauma. Finally, there are advanced radiological examinations. Advanced radiological modalities (such as magnetic resonance imaging and angiography) are carried out under the supervision of a specialist radiologist and generally adhering to the routine trauma protocol. Since most of the devices with advanced radiological examinations are 
not located directly adjacent to the trauma room, it should be ensured that the patient's condition is stable before transport (11).

\section{Materials and Methods}

In our study, we aimed to investigate the effects of prehospital fluid support on early radiological imaging and serum lactate levels on mortality and post-trauma recovery time.

\section{Study Design and Population}

In this retrospective study, 532 patients over the age of 18 years, who were admitted to the emergency department due to trauma between 1 January and 31 December 2017, were included. Patients with minor home accidents and cuts, patients who did not undergo the necessary examination and treatment in the emergency service, those with isolated head and neck trauma, and extremity trauma after the first 24 hours were excluded from the study. Demographic characteristics, trauma types, radiological images, organ injuries, fluid resuscitation, serum lactate levels, and blood results were evaluated.

In the study, patients were divided into two groups according to fluid resuscitation therapy. Data on whether these patients received fluid resuscitation were obtained from hospital automation and patient file records. Trauma patients were followed up retrospectively for three months with an automation system after they were discharged. Patients who did not visit hospital during this period were called by phone and the recovery period was questioned. Diagnoses, admission dates, contact information, demographic, clinical, and laboratory data are included in the registry system of our hospital. As a result, recovery levels three months after discharge were obtained from the patients and/or relatives and/or hospital records.

Traumas were divided into three general groups as falls (low and high), traffic accidents (inside and outside the vehicle), and penetrating (penetrating, cutting, and firearm injuries) injuries.

Post-traumatic recovery time (PRT) described the period of recovery and mobilization after the trauma patient was discharged. Patients who recovered and became active after discharge described those with mobilization who had extremity rest due to fractures, dislocations, and injuries and/or immobile patients after surgical operation after recovery. Patients in good general condition described those whose vital signs were defined as stable, conscious, not life-threatening, oriented and cooperative after they were evaluated in the emergency department. Patients with no complaints described those who were brought to the emergency service after trauma, whose general condition and physical examination were normal, and who needed to be followed up.

Apart from these, two groups were formed according to the presence or absence of thoracic vertebra, lumbar vertebra, thorax, and intraabdominal injuries. Two groups were evaluated considering whether or not fluid resuscitation was performed and whether there was mortality.

\section{Laboratory Design}

Arterial blood gas, lactate level, hemogram, and biochemical blood analyses of the patients were evaluated on admission to the emergency service.

Arterial blood gas; The lactate levels of the patients were obtained from arterial blood gas analysis using the Acobas ${ }^{\circledR}$ b221 Blood Gas system (Roche, Basel, Switzerland). Arterial blood gas results were analyzed in 5-10 minutes.

Hemogram blood analysis was performed using Sysmex DI-60 CBC Analyzer (Istanbul, Turkey). Biochemistry blood was analyzed by Beckman Coulter Automated AU-680 (Beckman Coulter, Inc., Fullerton, CA, USA). Hemogram and biochemistry results were studied in 45-60 minutes.

\section{Radiological Design}

Patients whose general condition was good had no complaints but they were brought to the emergency room for trauma and they were followed up in the emergency observation unit for a certain period. X-rays were not taken for them unless necessary. X-rays of patients with a good general condition, no thoracic and abdominal trauma, bruises, simple fractures, and dislocations were taken. Ultrasonography (USG) was planned in two ways. First, patients with good general conditions and stable vital signs were taken to the radiology unit. The other group included patients with the poor general condition and bad vital signs. Patient-Focused Assessment Sonography for Trauma was applied to these patients. CT, non-contrast, and/or contrast CT scans were performed for patients who could go to the radiology unit due to the general condition of thoracic and/or lumbar vertebral fracture, thoracic injury, abdominal organ injury, or bleeding. Multiple imaging was applied to patients with polytrauma. Resuscitation measures were taken in these patients and filming was performed in the presence of a physician. All USG and CTs were analyzed jointly with radiology, emergency, and related specialists. 
The study was conducted according to the Helsinki Declaration on human research, after getting approval from the local Ethics Board (2019-12/22).

\section{Statistical Analysis}

The data obtained from this study were analyzed with SPSS 20 (SPSS Inc., Chicago, IL, USA) package program. The Kolmogorov-Smirnov test was used while investigating the normal distributions of the variables. Descriptive statistics were presented as mean \pm standard deviation or median (minimum-maximum) for continuous variables and as the number of cases and percentage (\%) for nominal variables. When examining the differences between the groups, the Mann-Whitney U test was used because the variables did not come from the normal distribution. The chi-square analysis was used when examining the relationships between the groups of nominal variables. The Pearson's correlation analysis was used for assessing the linear relationship between variables. Receiver operating characteristic (ROC) curve analysis was performed to predict the development of mortality. When interpreting the results, values below the significance level of 0.05 were considered statistically significant.

\section{Results}

The average age of the patients was $37.19 \pm 13.91$ years, $378(71 \%)$ were male and $154(29 \%)$ were female. When the patients were evaluated in terms of biochemical, hematological, and arterial blood gas parameters, blood urea nitrogen, creatinine, alanine aminotransferase, aspartate aminotransferase, blood sugar, hematocrit values were not found to be significant in terms of trauma types. White blood cell was $10.45 \pm 3.90 \mathrm{mg} / \mathrm{dL}(\mathrm{p}=0.019)$ and the lactate level in blood gas was $2.37 \pm 1.23 \mathrm{mmol} / \mathrm{L}(\mathrm{p}=0.001)$ and it was significant. In addition, in the mortality group, lactate was found higher than in those living with $5.51 \pm 1.87$ $\mathrm{mmol} / \mathrm{L}(\mathrm{p}=0.001)$ and PRT $33.43 \pm 12.87$ days $(\mathrm{p}=0.004)$. PRT was found to be $22.48 \pm 7.17$ days and lactate level was $2.18 \pm 1.05 \mathrm{mmol} / \mathrm{L}(\mathrm{p}=0.001)$ in patients who underwent prehospital fluid resuscitation, which was significantly lower than in those who did not take fluid (Table 1).

There was no statistically significant difference in the distribution of trauma types by gender $(\mathrm{p}=0.410)$. Mortality was detected more in falls and traffic accidents with 6 (1.1\%) patients and penetrating injuries $(\mathrm{p}=0.003)$. Thoracic injuries were detected in $183(22.2 \%)$ and abdominal traumas in $25(4.7 \%)$ falls $(\mathrm{p}=0.001)$. In $10(1.9 \%)$ of the thoracic vertebra and $30(5.6 \%)$ of the lumbar vertebra injuries, the rate of a traffic accident was the highest $(\mathrm{p}=0.001)$. Fluid resuscitation was given in falls in 244 (45.9\%) patients ( $\mathrm{p}=0.016)$. X-ray, USG, and CT imaging were most frequently performed in falls. While 58 (10.9\%) of the traffic accident cases were performed CT imaging, it was found that none of the penetrating traumas was $\mathrm{X}$-rayed $(\mathrm{p}=0.001$, Table 2$)$.

A variable analysis of prehospital fluid resuscitation was not found to be significant in terms of gender, thoracic, and lumbar vertebral injuries. In the group receiving fluid resuscitation, mortality was high in 12 patients $(2.3 \%), 13$ patients with thoracic vertebrae (2.4\%), and 40 patients with abdominal trauma (7.5\%). Multiple radiological imaging was performed in the group of 38 (7.1\%) patients who did not receive fluid resuscitation. However, all other images were performed in the fluid resuscitation group ( $\mathrm{p}=0.001$, Table 3 ).

No relationship was found in the analysis of radiological images in terms of gender $(\mathrm{p}=0.203)$. Mortality was associated with multiple imaging in 10 (1.9\%), abdominal injuries in 47 (8.8\%), thoracic injuries in $16(3 \%)$, and lumbar vertebral injuries in 26 (4.9\%) patients. On the other hand, thoracic injuries were detected mostly on CT imaging in 157 (29.5\%) patients ( $\mathrm{p}=0.001$, Table 4$)$.

In the correlation analysis of the variables with radiological imaging, types of trauma and fluid resuscitation, a relationship between age and gender in all three parameters could not be determined. Considering trauma types, a moderate and/or strong positive correlation was observed with radiological imaging $(\mathrm{r}=0.405, \mathrm{p}=0.001)$, fluid resuscitation $(\mathrm{r}=0.115, \mathrm{p}=0.008)$, plasma lactate level $(\mathrm{r}=0.311, \mathrm{p}=0.001)$, PRT $(\mathrm{r}=0.105$, $\mathrm{p}=0.015)$, and mortality $(\mathrm{r}=0.177, \mathrm{p}=0.001)$. Considering fluid resuscitation, a strong positive relationship was found with radiological imaging $(\mathrm{r}=0.097, \mathrm{p}=0.025)$, plasma lactate level $(\mathrm{r}=0.174, \mathrm{p}=0.001)$, PRT $(\mathrm{r}=0.284$, $\mathrm{p}=0.001)$, and mortality $(\mathrm{r}=0.135, \mathrm{p}=0.002)$. Considering radiological imaging, a moderate and/or strong positive correlation was found with plasma lactate level $(r=0.677$, $\mathrm{p}=0.001)$, PRT $(\mathrm{r}=0.390, \mathrm{p}=0.001)$ and mortality $(\mathrm{r}=0.216$, $\mathrm{p}=0.001$ ). Correlation analysis of other parameters are given in Table 5.

"The ROC curve analysis" of mortality is shown in Figure 1. According to this analysis, the rates of lactate and PRT optimal cut-off value to predict the development of mortality were above $45 \%$, with a sensitivity of $97.7 \%$ and specificity of $94.3 \%$ for lactate [area under the curve (AUC): 
0.947, 95\% confidence interval: 0.908-0.986], and with a sensitivity of $89.7 \%$ and specificity of $83.6 \%$ for PRT (AUC: $0.724,95 \%$ confidence interval: 0.570-0.879).

\section{Discussion}

Trauma triage guidelines are typically based on the injury mechanism, detected injuries, and reported vital signs (5-8). Vital signs and physical examination findings vary individually and may cause patients with serious injuries to be overlooked. Standard parameters that give results within minutes that can be used in the initial evaluation of trauma patients are required. Serum lactate measurement, in addition to pre-hospital clinical evaluation, is a marker that has the potential to guide triage and further treatment decision-making (9-11). Ter Avest et al. (12), in their study on 156 trauma patients, showed that prehospital lactate levels correlated with the severity of trauma and the need for resuscitative in-hospital care. Similar results were obtained in previous multi-center studies, which stated that serum

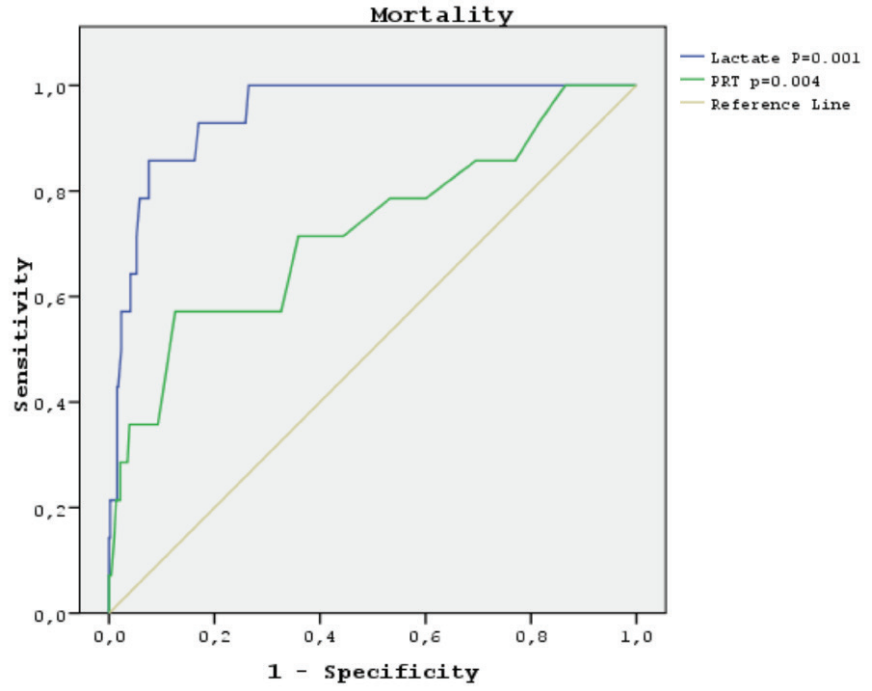

Figure 1. ROC curve analysis according to the mortality relationship between lactate and post-trauma recovery time of trauma patients

Table 1. Baseline characteristics and laboratory variables of the types of trauma

\begin{tabular}{|c|c|c|c|c|c|c|}
\hline & & \multirow[t]{2}{*}{ All patients } & \multicolumn{3}{|c|}{ Types of trauma } & \multirow{3}{*}{ p } \\
\hline & & & Fall & Traffic accident & Penetrating & \\
\hline \multicolumn{2}{|l|}{ Baseline characteristics } & Mean \pm SD & Mean \pm SD & Mean \pm SD & Mean \pm SD & \\
\hline \multicolumn{2}{|l|}{ Age, yr } & $37.19 \pm 13.91$ & $36.92 \pm 13.80$ & $38.52 \pm 14.03$ & $35.40 \pm 17.76$ & 0.415 \\
\hline \multicolumn{2}{|l|}{ Sex, female/male } & $154 / 378$ & $134 / 300$ & $29 / 69$ & $1 / 9$ & 0.410 \\
\hline \multicolumn{2}{|l|}{ PRT, day } & $24.44 \pm 7.66$ & $24.05 \pm 7.47$ & $25.87 \pm 8.10$ & $27.30 \pm 10.03$ & 0.095 \\
\hline \multicolumn{7}{|l|}{ Laboratory finding } \\
\hline \multirow[t]{6}{*}{ Biochemistry } & $\mathrm{BS}, \mathrm{mg} / \mathrm{dL}$ & $120.11 \pm 31.12$ & $119.56 \pm 32.00$ & $123.06 \pm 26.36$ & $114.70 \pm 37.42$ & 0.075 \\
\hline & $\mathrm{BUN}, \mathrm{mg} / \mathrm{dL}$ & $20.48 \pm 9.01$ & $20.62 \pm 9.29$ & $19.73 \pm 7.41$ & $22.01 \pm 10.82$ & 0.826 \\
\hline & Krea, mg/dL & $0.92 \pm 0.29$ & $0.93 \pm 0.30$ & $0.89 \pm 0.26$ & $0.98 \pm 0.31$ & 0.557 \\
\hline & $\mathrm{ALT}, \mathrm{mg} / \mathrm{dL}$ & $31.99 \pm 23.87$ & $31.85 \pm 24.84$ & $32.28 \pm 19.91$ & $35.26 \pm 18.56$ & 0.525 \\
\hline & $\mathrm{AST}, \mathrm{mg} / \mathrm{dL}$ & $30.70 \pm 26.28$ & $30.86 \pm 27.55$ & $29.35 \pm 20.53$ & $37.20 \pm 21.71$ & 0.353 \\
\hline & $\mathrm{ALP}, \mathrm{mg} / \mathrm{dL}$ & $10.56 \pm 55.08$ & $102.94 \pm 57.48$ & $101.10 \pm 42.75$ & $100.90 \pm 62.97$ & 0.704 \\
\hline \multirow[t]{3}{*}{ Hemogram } & $\mathrm{WBC}, \mathrm{mg} / \mathrm{dL}$ & $10.45 \pm 3.90$ & $10.25 \pm 3.91$ & $11.40 \pm 3.86$ & $9.77 \pm 2.23$ & 0.019 \\
\hline & $\mathrm{Hb}, \mathrm{g} / \mathrm{dL}$ & $14.08 \pm 1.91$ & $14.10 \pm 1.86$ & $14.01 \pm 2.04$ & $14.24 \pm 2.72$ & 0.877 \\
\hline & $\mathrm{Hct}, \%$ & $42.36 \pm 7.18$ & $42.30 \pm 7.15$ & $42.51 \pm 7.18$ & $43.26 \pm 8.66$ & 0.723 \\
\hline \multirow{3}{*}{\multicolumn{2}{|c|}{ Lactate, $\mathrm{mmol} / \mathrm{L}$}} & $2.37 \pm 1.23$ & $2.19 \pm 1.07$ & $3.02 \pm 1.42$ & $3.88 \pm 2.31$ & 0.001 \\
\hline & & Mortality & & & & \\
\hline & & No & & Yes & & \\
\hline \multicolumn{2}{|l|}{ PRT, day } & $24.20 \pm 7.34$ & & $33.43 \pm 12.87$ & & 0.00 \\
\hline \multirow{3}{*}{\multicolumn{2}{|c|}{ Lactate, mmol/L }} & $2.29 \pm 1.10$ & & $5.51 \pm 1.87$ & & 0.001 \\
\hline & & \multicolumn{4}{|c|}{ Fluid resuscitation } & \\
\hline & & No & & Yes & & \\
\hline \multicolumn{2}{|l|}{ PRT, day } & $26.85 \pm 7.58$ & & $22.48 \pm 7.17$ & & 0.001 \\
\hline \multicolumn{2}{|l|}{ Lactate, $\mathrm{mmol} / \mathrm{L}$} & $2.61 \pm 1.40$ & & $2.18 \pm 1.05$ & & 0.001 \\
\hline
\end{tabular}

SD: Standard deviation, Yr: Year, PRT: Posttraumatic recovery time, BS: Blood sugar, BUN: Blood urea nitrogen, Krea: Creatinine, ALT: Alanine aminotransferase, AST: Aspartate aminotransfersez, ALP: Alkaline phosphates, WBC: White blood cell, Hb: Hemoglobin, Hct: Hematocrit 
Table 2. Analysis of types of trauma with variables

\begin{tabular}{|c|c|c|c|c|c|}
\hline & & \multicolumn{3}{|c|}{ Types of trauma } & \multirow[b]{2}{*}{$\mathbf{p}$} \\
\hline & & Fall n (\%) & Traffic accident $\mathrm{n}(\%)$ & Penetrating n ( \%) & \\
\hline \multirow[t]{2}{*}{ Gender } & Female & $124(23.3)$ & $29(5.5)$ & $1(0.2)$ & 0.410 \\
\hline & Male & $300(56.4)$ & $69(13)$ & $9(1.7)$ & \\
\hline \multirow[t]{2}{*}{ Mortality } & No & $418(78.6)$ & $92(17.3)$ & $8(1.5)$ & 0.003 \\
\hline & Yes & $6(1.1)$ & $6(1.1)$ & $2(0.4)$ & \\
\hline \multirow[t]{2}{*}{ Thorax } & No & $306(57.5)$ & $15(2.8)$ & $1(0.2)$ & 0.001 \\
\hline & Yes & $118(22.2)$ & $83(15.6)$ & $9(1.7)$ & \\
\hline \multirow[t]{2}{*}{ Thoracic vertebra } & No & $418(78.6)$ & $88(16.5)$ & $9(1.7)$ & 0.001 \\
\hline & Yes & $6(1.1)$ & $10(1.9)$ & $1(0.2)$ & \\
\hline \multirow[t]{2}{*}{ Lumbar vertebra } & No & $411(77.3)$ & $68(12.8)$ & $7(1.3)$ & 0.001 \\
\hline & Yes & $13(2.4)$ & $30(5.6)$ & $3(0.6)$ & \\
\hline \multirow[t]{2}{*}{ Abdominal } & No & $399(75)$ & $74(13.9)$ & $6(1.1)$ & 0.001 \\
\hline & Yes & $25(4.7)$ & $24(4.5)$ & $4(0.8)$ & \\
\hline \multirow[t]{2}{*}{ Fluid resuscitation } & No & $180(33.8)$ & $51(9.6)$ & $8(1.5)$ & 0.016 \\
\hline & Yes & $244(45.9)$ & $47(8.8)$ & $2(0.4)$ & \\
\hline \multirow[t]{5}{*}{ Radiological imaging } & No & $56(10.5)$ & $3(0.6)$ & 0 & 0.001 \\
\hline & X-ray & $125(23.9)$ & $9(1.7)$ & 0 & \\
\hline & USG & $120(22.6)$ & $3(0.6)$ & $1(0.2)$ & \\
\hline & BT & $102(19.2)$ & $58(10.9)$ & $5(0.9)$ & \\
\hline & Multiple & $21(3.9)$ & $25(4.7)$ & $4(0.8)$ & \\
\hline
\end{tabular}

Table 3. Analysis with variables according to pre-hospital fluid resuscitation

\begin{tabular}{|c|c|c|c|c|}
\hline & & Fluid resu & citation & \\
\hline & & $\begin{array}{l}\text { No } \\
\text { n (\%) }\end{array}$ & $\begin{array}{l}\text { Yes } \\
\text { n (\%) }\end{array}$ & $\mathbf{p}$ \\
\hline Gender & Female & $78(14.7)$ & $76(14.3)$ & 0.090 \\
\hline & Male & $161(30.3)$ & $217(40.8)$ & \\
\hline Mortality & No & $227(42.7)$ & $291(54.7)$ & 0.002 \\
\hline & Yes & $12(2.3)$ & $2(0.4)$ & \\
\hline Thorax & No & $145(27.3)$ & $177(33.3)$ & 0.951 \\
\hline & Yes & $94(17.7)$ & $116(21,8)$ & \\
\hline Thoracic vertebra & No & $226(42.5)$ & $289(54.3)$ & 0.008 \\
\hline & Yes & $13(2.4)$ & $4(0.8)$ & \\
\hline Lumbar vertebra & No & $213(40)$ & $273(51.3)$ & 0.098 \\
\hline & Yes & $26(4.9)$ & $20(3.8)$ & \\
\hline Abdominal & No & $199(37.4)$ & $280(52.6)$ & 0.001 \\
\hline & Yes & $40(7.5)$ & $13(2.4)$ & \\
\hline Radiological & No & $22(4.1)$ & $37(7)$ & 0.001 \\
\hline & X-ray & $58(10.9)$ & $768(14.3)$ & \\
\hline & USG & $59(11.1)$ & $65(12.2)$ & \\
\hline & BT & $62(11.7)$ & $103(19.4)$ & \\
\hline & Multiple & $38(7.1)$ & $12(2.3)$ & \\
\hline
\end{tabular}

lactate levels could be an effective criterion in guiding the initial evaluation and resuscitative treatment of trauma patients. They also suggested that the lactate level could be used to predict trauma mortality and morbidity (13-16). In the study, high lactate level was found in patients who did not undergo prehospital fluid resuscitation. In this case, it was determined that there was an increase in mortality in the acute period and a prolongation in post-traumatic recovery in the late period. We think that pre-hospital fluid resuscitation in trauma patients will be an important indicator in terms of shortening the late PRT. Also, the fact that a significant difference was found in terms of mortality may be an important parameter in terms of fluid resuscitation and serum lactate level in future studies.

Lactate formation in body metabolism occurs as a result of anaerobic glycolysis by causing bleeding, insufficient ventilation, hypovolemia, hypoxemia, and end-organ hypoperfusion following a traumatic injury $(17,18)$. However, in the last decade, it has become clear that accelerated aerobic glycolysis (beta adrenergically mediated) also contributes significantly to lactate formation under a variety of conditions. Intense adrenergic discharge increases lactate formation in trauma patients (19).

Intense sympathetic activation and adrenergic stimulation occur in trauma patients for hypovolemic compensation secondary to possible bleeding and due to pain and stress (17). In some studies, it is aimed to control lactate production by modifying beta-adrenergic stimulation 
with different treatment regimens $(13,14)$. Of course, since these treatments do not affect pre-hospital lactate levels, they do not restrict the use of lactate measurement as a prognostic marker for end-organ hypoperfusion and morbidity. In their study, Kruse et al. (20) suggested that the results obtained by blood lactate monitoring and especially serial lactate sampling were valuable in predicting in-hospital mortality in the risk assessment of patients who were acutely admitted to the hospital. In this study, it has been recommended that all patients with lactate above $2.5 \mathrm{~mm}$ on admission require close clinical follow-up, and serial lactate samples should be taken in patients with lower lactate levels (20). In the study, prehospital fluid resuscitation has a significant relationship with lactate and recovery, as well as in-hospital mortality. Also, radiological imaging was found to be easier and faster in patients with fluid intake in terms of hemodynamic stability. This resulted in mortality, length of hospital stay, better hemodynamic parameters, and rapid transport of the patients to be operated on.

The type of trauma or mechanism of tissue damage is associated with lactate levels. In previous studies, it was observed that pulse fullness, heart rate, systolic blood pressure, shock index, oxygen saturation, and end-tidal carbon dioxide levels were correlated with plasma lactate levels $(12,16)$. Pain and/or stress experienced by trauma patients contributes to prehospital lactate levels. In our study, the relationship between pain and lactate could not be directly evaluated. However, it was observed that prehospital fluid supplementation decreased lactate levels. It is well known that fluid administration and adequate analgesia dull the physiological stress response and limit endogenous catecholamine release, resulting

Table 4. Analysis of radiological imaging methods with variables

\begin{tabular}{|c|c|c|c|c|c|c|c|}
\hline & & \multicolumn{5}{|c|}{ Radiological imaging } & \multirow[b]{2}{*}{$\mathbf{p}$} \\
\hline & & $\begin{array}{l}\text { No } \\
\text { n (\%) }\end{array}$ & $\begin{array}{l}\text { X-ray } \\
\text { n (\%) }\end{array}$ & $\begin{array}{l}\text { USG } \\
\text { n (\%) }\end{array}$ & $\begin{array}{l}\text { BT } \\
\text { n (\%) }\end{array}$ & $\begin{array}{l}\text { Multiple } \\
\text { n (\%) }\end{array}$ & \\
\hline \multirow[t]{2}{*}{ Gender } & Female & $14(2.6)$ & $47(8.8)$ & $28(5.3)$ & $49(9.2)$ & $16(3)$ & 0.203 \\
\hline & Male & $45(8.5)$ & $87(16.4)$ & $96(18)$ & $116(21.8)$ & $34(6.4)$ & \\
\hline \multirow[t]{2}{*}{ Mortality } & No & $59(11.1)$ & $134(25.2)$ & $122(22.9)$ & $163(30.6)$ & $40(7.5)$ & 0.001 \\
\hline & Yes & 0 & 0 & $2(0.4)$ & $2(0.4)$ & $10(1.9)$ & \\
\hline \multirow[t]{2}{*}{ Thorax } & No & $59(11.1)$ & $125(23.5)$ & $123(23.1)$ & $8(1.5)$ & $7(1.3)$ & 0.001 \\
\hline & Yes & 0 & $9(1.7)$ & $1(0.2)$ & $157(29.5)$ & $43(8.1)$ & \\
\hline \multirow[t]{2}{*}{ Thoracic vertebra } & No & $59(11.1)$ & $134(25.2)$ & $124(23.3)$ & $164(30.8)$ & $34(6.4)$ & 0.001 \\
\hline & Yes & 0 & 0 & 0 & $1(0.2)$ & $16(3)$ & \\
\hline \multirow[t]{2}{*}{ Lumbar vertebra } & No & $59(11.1)$ & $134(25.2)$ & $124(23.3)$ & $145(27.3)$ & $24(4.5)$ & 0.001 \\
\hline & Yes & 0 & 0 & 0 & $20(3.8)$ & $26(4.9)$ & \\
\hline \multirow[t]{2}{*}{ Abdominal } & No & $59(11.1)$ & $133(25)$ & $123(23.1)$ & $161(30.3)$ & $3(0.6)$ & 0.001 \\
\hline & Yes & 0 & $1(0.2)$ & $1(0.2)$ & $4(0.8)$ & $47(8.8)$ & \\
\hline
\end{tabular}

Table 5. Correlation analysis of radiological imaging methods, types of trauma and fluid resuscitation with variables

\begin{tabular}{|c|c|c|c|c|c|c|}
\hline & \multicolumn{2}{|c|}{ Radiological imaging } & \multicolumn{2}{|c|}{ Types of trauma } & \multicolumn{2}{|c|}{ Fluid resuscitation } \\
\hline & $\mathbf{r}$ & $\mathbf{p}$ & $\mathbf{r}$ & $\mathbf{p}$ & $\mathbf{r}$ & $\mathbf{p}$ \\
\hline Radiological imaging & 1 & & 0.405 & 0.001 & 0.097 & 0.025 \\
\hline Types of trauma & 0.405 & 0.001 & 1 & & 0.115 & 0.008 \\
\hline Fluid resuscitation & 0.097 & 0.025 & 0.115 & 0.008 & 1 & \\
\hline Lactate & 0.677 & 0.001 & 0.311 & 0.001 & 0.174 & 0.001 \\
\hline PRT & 0.390 & 0.001 & 0.105 & 0.015 & 0.284 & 0.001 \\
\hline Age & 0.056 & 0.195 & 0.028 & 0.521 & 0.003 & 0.952 \\
\hline Gender & -0.008 & 0.856 & 0.029 & 0.511 & -0.073 & 0.091 \\
\hline Mortality & 0.216 & 0.001 & 0.177 & 0.001 & 0.135 & 0.002 \\
\hline Thorax & 0.749 & 0.001 & 0.456 & 0.001 & -0.003 & 0.951 \\
\hline Lumbar vertebra & 0.403 & 0.001 & 0.376 & 0.001 & 0.072 & 0.098 \\
\hline Thoracic vertebra & 0.296 & 0.001 & 0.192 & 0.001 & 0.115 & 0.008 \\
\hline Abdominal & 0.511 & 0.001 & 0.277 & 0.001 & 0.204 & 0.001 \\
\hline
\end{tabular}


in a decrease in glycolysis rate (21). In our study, lactate and mortality were found to be higher in trauma type of penetrating injuries. Also, the significant correlation of trauma causes with fluid resuscitation, radiological imaging, mortality, and lactate should be considered. In similar studies, the number of studies showing that the effect of fluid resuscitation increases mortality in patients with penetrating trauma has increased in recent years (2225). However, since the mechanism of penetrating trauma and the mechanism of blunt trauma are different from each other, it may be expected that fluid resuscitation may be beneficial in patients with blunt trauma (26). Mizushima et al. (23) stated that limited fluid resuscitation may be beneficial. On the other hand, it has been predicted that the aggressive administration of pre-hospital intravenous fluid therapy may lead to the opening of clots formed as a result of increasing blood pressure and causing recurrent bleeding $(25,26)$. Therefore, limited fluid therapy is recommended only in hypotensive patients.

These factors may be the reason for the different results obtained in studies with lactate measurements. In the evaluation of lactate levels, not only pre-hospital and initial evaluation results but also serial laboratory measurements will provide enlightening and correlated results in the evaluation of organ damage and comorbidities, and shed light on advanced treatment methods.

\section{Study Limitations}

There were some limitations in our study. The most important of these is that it is single-center and retrospective. Also, difficulties in accessing hospital records, patients, and/or patients' relatives by phone were other important limitations.

\section{Conclusion}

Lactate levels that give rapid results in trauma patients are a parameter associated with the type of injury, treatment at the scene, and final organ perfusion and oxygenation rates, which also show the effect of many factors that cannot be measured. Lactate values also need to be taken into account in the application of clinical algorithms to guide prehospital triage or treatment.

\section{Ethics}

Ethics Committee Approval: The study was conducted according to the Helsinki Declaration on human research, after getting approval from the local Ethics Board (201912/22).
Informed Consent: Patient consent was obtained.

Peer-review: Externally and internally peer-reviewed.

\section{Authorship Contributions}

Concept: F.T.T., A.C., Design: FT.T., A.C., Data Collection or Processing: FT.T., A.C., Analysis or Interpretation: F.T.T., A.C., Writing: F.T.T.

Conflict of Interest: No conflict of interest was declared by the authors.

Financial Disclosure: The authors declared that this study received no financial support.

\section{References}

1. The Global Burden of Disease 2004 Update. Geneva: World Health Organization, 2004. Avaialable from: https://apps.who.int/iris/ handle/10665/43942.

2. Lin ML, Kolosh KP, Fearn KT. Injury Facts. Itasca, IL: National Safety Council, 2011:1-6.

3. Henry JA, Reingold AL. Prehospital trauma systems reduce mortality in devoloping countries: a systemic review and metaanalysis. J Trauma Acute Care Surg 2012:73(1):261-268.

4. Holcomb JB, Wade CE, Brasel KJ, Vercruysse G, Macleod J, Dutton RP, et al; Trauma Outcomes Group. Defining present blood component transfusion practices in trauma patients: papers from the Trauma Outcomes Group. J Trauma 2011;71(2 Suppl 3):S315-S317. doi: 10.1097/TA.0b013e318227ed13.

5. Seamon MJ, Fisher CA, Gaughan J, Lloyd M, Bradley KM, Santora RA, et al. Prehospital procedures before emergency department thoracotomy: "Scoopand Run" saveslives. J Trauma Acute Care Surg 2007;63(1):113-120.

6. Kauvar DS, Lefering R, Wade CE. Impact of hemorrhage on trauma outcome: an overview of epidemiology, clinical presentations, and therapeutic considerations. J Trauma 2006;60(6):3-11.

7. Salomone JP, Ustin JS, McSwain NE Jr, Feliciano DV. Opinions of trauma practitioners regarding prehospital interventions for critically injured patients. J Trauma 2005;58:509-515.

8. Mizushima Y, Nakao S, Idoguchi K, Matsuoka T. Fluid resuscitation of trauma patients: How much fluid is enough to determine the patient's response? Am J Emerg Med 2017;35(6):842-845.

9. Baydın A, Yardan T, Güven H, Dervişoğlu A, Otal Y, Eden AO, et al. The relation of the lactate, base excess and Injury Severity Scores (ISS) with mortality in trauma. Turk J Emerg Med 2007;7(3):97101

10. Dübendorfer C, Billeter AT, Seifert B, Keel M, Turina M. Serial lactate and admission SOFA scores in trauma: an analysis of predictive value in 724 patients with and without traumatic brain injury. Eur J Trauma Emerg Surg 2013;39(1):25-34.

11. Oyar O, Gülsoy UK. Radiological Approach to Patients with Polytrauma. STED 2002;11(2):67-68.

12. Ter Avest E, Griggs J, Wijesuriya J, Russell MQ, Lyon RM. Determinants of prehospital lactate in trauma patients: a retrospective cohort study. BMC Emerg Med 2020;20(1):18. 
13. Mullen M, Cerri G, Murray R, Talbot A, Sanseverino A, McCahill P, et al. Use of point-of-care lactate in the prehospital aeromedical environment. Prehosp Disaster Med 2014;29(2):200-203.

14. Brown JB, Lerner EB, Sperry JL, Billiar TR, Peitzman AB, Guyette FX. Prehospital lactate improves accuracy of prehospital criteria for designating trauma activation level. J Trauma Acute Care Surg 2016;81(3):445-452.

15. Martín-Rodríguez F, López-Izquierdo R, Castro Villamor MA, Mangas IM, Del Brío IP, Delgado Benito JF, et al. Prognostic value of lactate in prehospital care as a predictor of early mortality. Am J Emerg Med 2019;37(9):1627-1632.

16. Guyette FX, Meier EN, Newgard C, McKnight B, Daya M, Bulger EM, et al. A comparison of prehospital lactate and systolic blood pressure for predicting the need for resuscitative care in trauma transported by ground. J Trauma Acute Care Surg 2015;78(3):600606.

17. Kushimoto S, Akaishi S, Sato T, Nomura R, Fujita M, Kudo D, et al. Lactate, a useful marker for disease mortality and severity but an unreliable marker of tissue hypoxia/hypoperfusion in critically ill patients. Acute Med Surg 2016;3(4):293-297.

18. Lewis CT, Naumann DN, Crombie N, Midwinter MJ. Prehospital point-of-care lactate following trauma: a systematic review. J Trauma Acute Care Surg 2016;81:748-755.

19. Levy B, Desebbe O, Montemont C, Gibot S. Increased aerobic glycolysis through beta2 stimulation is a common mechanism involved in lactate formation during shock states. Shock 2008;30(4):417-421.
20. Kruse O, Grunnet N, Barfod C. Blood lactate as a predictor for in-hospital mortality in patients admitted acutely to hospital: a systematic review. Scand J Trauma Resusc Emerg Med 2011;19:74.

21. Gjedsted J, Buhl M, Nielsen S, Schmitz O, Vestergaard ET, Tønnesen E, et al. Effects of adrenalin on lactate, glucose, lipid and protein metabolism in the placebo controlled bilaterally perfused human leg. Acta Physiol (Oxf) 2011;202(4):641-648.

22. Bickell WH, Wall MJ, Pepe PE, Martin RR, Ginger VF, Allen $\mathrm{MK}$, et al. Immediate versus delayed fluid resuscitation for hypotensive patients with penetrating torso injuries. N Engl J Med 1994;331(17):1105-1109.

23. Mizushima Y, Nakao S, Idoguchi K, Matsuoka T. Fluid resuscitation of trauma patients: How much fluid is enough to determine the patient's response? Am J Emerg Med 2017;35(6):842-845.

24. Dübendorfer C, Billeter AT, Seifert B, Keel M, Turina M. Serial lactate and admission SOFA scores in trauma: an analysis of predictive value in 724 patients with and without traumatic brain injury. Eur J Trauma Emerg Surg 2013;39(1):25-34.

25. Dula DJ, Wood GC, Rejmer AR, Starr M, Leicht M. Use of prehospital fluids in hypotensive blunt trauma patients. Prehosp Emerg Care 2002;6(4):417-420.

26. Duke MD, Guidry C, Guice J, Stuke L, Marr AB, Hunt JP, et al. Restrictive fluid resuscitation in combination with damage control resuscitation: time for adaptation. J Trauma Acute Care Surg 2012;73(3):674-678. 